\title{
A Study of Prolactin, Thyroid Stimulating Hormones, Malondialdehyde and Ceruloplasmin Levels in Infertile Women, in Thi-Qar Governorate/Iraq
}

\author{
Rawaa Abdulmutalib M. Hussein*, Prof. Dr. Raid M. H. Al-Salih*, Prof. \\ Dr. Saher Abdul Rutha Ali * \\ * Department of Chemistry, College of Science, Thi-Qar University, Iraq
}

\begin{abstract}
OBJECTIVES: The study designed to investigate the level of prolactin (PRL), thyroid-stimulating hormones, Malondialdehyde (MDA) and ceruloplasmin (Cp) levelsof the groups of infertile and fertile females in Nasiriyah province, southern Iraq.
\end{abstract}

METHODOLOGY: Blood samples were collected from two groups of females (females with infertility and fertile women) with a total number of 99 infertile women and 70 fertile females at Bent Al-Huda maternity and children teaching hospital in Thi-Qar governorate. Autoanalyzercobas e411 instrument was used to estimate of prolactin, Thyroid-stimulating hormones and Ceruloplasmin levels in sera of patients and control group using Elecsys and cobas immunoassay analyzers. The MDA level of the serum was measured by the modified method of Fong et al. (1973). The concentration of plasma MDA was computed according to the equation of coefficient of MDA equal to $1.56 \times 10^{3} \mathrm{~mol}^{-1}$. $\mathrm{cm}^{-1}$.

RESULTS: Prolactin and TSH levels were significantly increased $(\mathrm{p}<0.0001)$ in infertile females as compared to fertile women. A similar pattern was observed to concentrations of MDA and Ceruloplasmin were significantly increased ( $p<0.0001)$ in patients when compared to control group.

CONCLUSION:The results of this study indicate that oxidative stress does occur in infertile females. Patients with infertility showed are higher significant rise in serum Prolactin hormone and thyroid-stimulating hormone levels in infertility patient group. All the patients with a high Prolactin level should have TSH estimation.

\section{INTRODUCTION:}

Infertility is the inability of a couple to achieve pregnancy over an average period of one year (in a woman under 35 years of age) or 6 months (in a woman above 35 years of age) despite adequacy ${ }^{1}$. Infertility may also be referred to as the inability to carry a pregnancy to the delivery of a live baby. Infertility can be due to the woman, the man, or both; primary or secondary. Ovulation problems are the most common causes of infertility and 
can arise as a result of a defect in hypothalamus, pituitary or ovary ${ }^{1}$. Hypothalamic disorder is most commonly due to weight loss, eating disorder, excessive exercise and hypothalamic lesions. Pituitary disorders include hyperprolactinemia ,thyroid disease, Cushing disease and Sheehan syndrome ${ }_{2}^{2}$ Ovarian dysfunctions are most commonly due to polycystic ovarian syndrome (POS), less common aetiology is premature ovarian failure ${ }^{3}$.

Hyperprolactinemia is a common problem in reproductive dysfunction affecting about one third of infertile women. It has beensuggested that hypogonadism seen in hyperprolactinemic women is due to circulating levels of prolactininterfering with the action of the gonadotrophins at the ovarian level and impaired gonadal steroid secretionGonadotrophins, in turn alters positive feedback effects on the hypothalmic and pituitary levels. This leads to lack of gonatotrophincyclicity and infertility. Prolactin can inhibit the follicular estradiolproduction and this result in infertility ${ }^{4}$.

TSH stimulates the thyroid gland to secrete the hormones T4 and T3. The production of TSH is controlled by a thyrotropin releasing hormone (TRH), which is manufactured in the hypothalamus and transported to the anterior pituitary gland via the superior hypophyseal artery, where it increases TSH production and release. A high level of TSH stimulates prolactin secretion and causes ovulatory dysfunction and leading to infertility ${ }^{5}$. When cells use oxygen to generate energy, free radicals are createdas a consequence of ATP (adenosine triphosphate) production by the mitochondria. These by-products are generally reactive oxygen species (ROS) as well as reactive nitrogen species (RNS) that result from the cellular redox process ${ }^{6}$.

These species play a dual role as both toxic and beneficial compounds. At low or moderate levels, ROS and RNS exert beneficial effects on cellular responses and immune function. At high concentrations, they generate oxidative stress, a deleterious process that can damage all cell structures ${ }^{7}$. Many human studies reported the presence of ROS in the femalereproductive tract and their role in its physiological functions such as oocyte maturation, ovarian steroidogenesis and corpus maturation $^{8}$.Also ROS may be produced during embryo metabolism and from its surroundings 9 .

Nitric oxide (NO) is synthesized during the enzymatic conversionof Larginine to L-citrulline by nitric oxide synthase (NOS) . It is a highly reactive free radical, damages proteins, carbohydrates, nucleotides and lipids results in cell and tissue damage. The two common examples of reactive nitrogen species are nitric oxide (NO) and nitrogen dioxide. NO is produced by the enzyme NO synthase ${ }^{10}$.Inducible NO synthase (iNOS) is present in monocytes andmacrophages and produces a large amount of NO. During the folliculardevelopment in the ovaries, NO synthase is expressed on the surface of the oocyte ${ }^{9}$.Antioxidants are molecules that can prevent the oxidation ofother molecule. Oxidation is a chemical reaction that transfers an electron from a molecule to an oxidizing agent. There are two types of antioxidants: enzymatic and non-enzymatic. These two types of antioxidant system are working together to ameliorate anyharmful effects of oxidant in the cell, both of the enzymatic and nonenzymaticantioxidants detoxify ROS in the intracellular and 
extracellular environments ${ }^{11}$.Many human studies reported the presence of ROS in the femalereproductive tract and their role in its physiological functions such as oocyte maturation, ovarian steroidogenesis and corpus maturation ${ }^{8}$.

Ceruloplasmin is a ferroxidase enzyme that in humans is encodedby the $\mathrm{CP}$ gene ${ }^{12}$. Ceruloplasmin binds copper; appears to be more important as a copper storage pool than as a transport protein; integrates iron and copper homeostasis ${ }^{13}$. In addition, $\mathrm{Cp}$ is an effective antioxidant because of its ability tooxidize highly toxic ferrous iron to the relatively nontoxic ferric form and thus help prevent oxidative damage to proteins, lipids and DNA ${ }^{14}$. Malondialdehyde is an end product of lipid peroxidation (LPO) which is a processwhere reactive oxygen species degrade polyunsaturated lipids. Thiscompound is reactive aldehyde and is one of the many reactive electrophile species that cause toxic stress in cells and for advanced glycation end products ${ }^{15}$. The production of this aldehyde is used as a biomarker to measure the level of oxidative stress in an organism ${ }^{16}$.

\section{MATERIALS AND METHODS:}

This study was conducted as a casecontrol study at Bent Al-Huda maternity and childrenTeaching Hospital in Thi-Qar governorate. The study was carried out inthe unit of the laboratory Department of Clinical Biochemistry. Informed consentwas obtained verbally from all participants. A total of ninety nine womenwith infertility of the ages $18-45$ years and duration of infertility more than one year who were diagnosed by gynaecology and obstetrics. To compare the results, seventy healthy age matched females with a history of at least one childbirth were also enrolled.

Five $\mathrm{ml}$ of blood samples from patients and control groups was collected by vein puncture using asterile disposable syringe in plain plastic tubes. The serum was separated

immediately in order to allow to clot at room temperature. The blood was centrifuged at 3000 rotor per minute (rpm) for 10 minutes and stored in plain tubes at $-200 \mathrm{C}$ until used or immediately analysed.

\section{Determination of Serum Malondialdehyde (MDA):}

In this method, lipid peroxidation reacts with thiobarbituric acid (TBA) in coexisting trichloroacetic acid (TCA) to give a pink chromophore. The MDA level of the serum sample was estimated by the modified method of Fong et al., $(1973)^{17}$. The level of MDA was computed according to the equation of coefficient of MDA equal to $1.56 \times 10^{3} \mathrm{~mol}^{-1} \cdot \mathrm{cm}^{-1}$.

\section{Estimation of serum prolactin and TSH:}

Prolactin and TSH determination kits wereobtained from Roche diagnostics and determined in Elecsys2010, autoanalyzercobas e411 instrument.

\section{Estimation of serum Antioxidants (serum Ceruloplasmin)}

Ceruloplasmin estimation kit wasobtained from Roche diagnostics and determined by clinical chemistry analyzer cobas c311 in serum samples using cobas e immunoassay analyzer instrument.

\section{Statistical Analysis}

Statistical analysis was done using the software SPSS version 15.0; the results were expressed as mean \pm standard deviations (SD). One way ANOVAtest was used to compare parameters in 
different studied groups. $\mathrm{P}$-values $(\mathrm{P}<$ 0.0001 and $\mathrm{P}<0.05)$ were considered statistically significant.

\section{RESULTS:}

In this study, we estimated the levels of Prolactin, TSH, MDA and ceruloplasmin among infertile and fertile females. The levels of serum prolactin hormone in the infertile women's group showed a highly significant increase $(\mathrm{P}<0.0001)$ in comparison with their control group (Table 1). The mean serum TSH levels in infertile patients were $2.70 \pm 1.42$ $\mu \mathrm{IU} / \mathrm{ml}$ against the controls who had a mean serum TSH level of $1.89 \pm 1.11 \mu \mathrm{IU} / \mathrm{ml}$ and both groups are statistically significantly different to eachother $(\mathrm{p}$ value $=<0.0001)$ (Table 2). The serum ceruloplasmin and MDA levels were found to be significantly increased $(\mathrm{P}<0.0001$ and $\mathrm{P}<0.0001$, respectively) in patients with infertility compared to control group (Table 3 and Table 4).

Table 1:Serum Prolactin level in infertile females compared with control group.

\begin{tabular}{|l|l|l|l|}
\hline Parameter & Group & No. & Mean \pm SD \\
\hline $\begin{array}{l}\text { Prolactin } \\
\text { Level } \\
(\boldsymbol{\mu I U})\end{array}$ & Control & 70 & $10.35 \pm 6.08$ \\
\cline { 2 - 4 } & Infertile & 99 & $20.29 \pm 17.09^{\mathrm{a}^{* *}}$ \\
\hline
\end{tabular}

(a) :significant between patients with infertility and control group.

$* * \mathrm{P}<0.0001$

Table 2: Serum TSH level in infertile women compared with control group.

\begin{tabular}{|c|l|l|c|}
\hline Parameter & Group & No. & Mean \pm SD \\
\hline TSH Level & Control & 70 & $1.89 \pm 1.11$ \\
\hline$(\mu$ IU) & Infertile & 99 & $2.70 \pm 1.42^{a^{* *}}$ \\
\hline
\end{tabular}

- Legend as in table (1)

Table 3: Level of Serum Ceruloplasmin in Infertile females and control group.

\begin{tabular}{|l|l|c|c|}
\hline Parameter & Group & No. & Mean \pm SD \\
\hline Ceruloplasmin & Control & 70 & $0.29 \pm 0.08$ \\
\hline \multirow{2}{*}{ Level (g/L) } & Infertile & 99 & $0.40 \pm 0.09^{\mathrm{a}^{* *}}$ \\
\hline
\end{tabular}

- Legend as in table (1)

Table 4: Level of Serum Malondialdehyde in Infertile females and control group.

\begin{tabular}{|l|c|c|c|}
\hline Parameter & Group & No. & Mean \pm SD \\
\hline $\begin{array}{l}\text { MDA } \\
\text { Level } \\
(\mathbf{m g} / \mathbf{m l})\end{array}$ & Control & 70 & $54.79 \pm 7.46$ \\
\hline
\end{tabular}

- $\quad$ Legend as in table (1)

\section{DISCUSSION:}

The failure to identify a clear cause of the infertility after a full screening of females is defined as infertility of unknown cause ${ }^{18}$. The increased function of the thyroid is likely to cause disorders in menstrual cycle and an increase or decrease in women's sexual activity. The decrease function of the gland causes a decrease in sexual activity. Also, other problems may be due to thecause of thyroid dysfunction. Disorders of the pituitary gland, on the other hand, may cause decreased function of the thyroid ${ }^{19}$. The mean serum TSH levels in infertile patients were $2.70 \pm 1.42 \mu \mathrm{IU} / \mathrm{ml}$ 
against the controls who had a mean serum TSH level of $1.89 \pm 1.11 \mu \mathrm{IU} / \mathrm{ml}$ and both groups are statistically significantly different to each other. These results are in agreement with results of ${ }^{20,21}$.

Thyroid hormones have profound effects on reproduction and pregnancy. TRH is under negative feedback control of TSH through a short negative feedback loop; that is any increase in TSH will decrease the release of TRH which in turn will inhibit the secretion of prolactin and will also normalize the TSH levels. The relationships between TSH, prolactin and female infertility are multiple and complex. Thyrotropinreleasing hormone is a potent stimulus of prolactin and the association between hypothyroidism and hyperprolactinemiais well appreciated. Hyperprolactinemia, because of a variety of causes, can reduce pulsatile Gonadatropin releasing hormone secretion and interfere with ovulation 22.

Prolactin hormone shows a highly significant increase in the infertile women's group in comparison with their control group. Prolactin is one of several hormones that is producedby the pituitary gland. The most important role of prolactin is to stimulate milk production in women after the delivery of a baby ${ }^{23}$. This study is agreement with the findings of Mohammed A. Z (2003) increased prolactin in patients with infertility in comparison with control group may be due to low oestrogen and progesterone levels in the infertile women results in a decrease in serum LH and FSH in infertile women ${ }^{24}$. According to EmoKpae et al, there maybe failure of the hypothalamus or pituitary gland, which result in increasedserum prolactin levels and leads to infertility ${ }^{23}$.This study agrees with a study done by Nissreen F. A. et al. (2014) andIqbal NajiTawfiq (2013) suspected that the infertile women withovulation disorder had increased prolactin due to an inadequate corpus luteal progesterone secretion ${ }^{25,26}$.

Elevated levels of prolactin cause infertility becauseprolactin inhibits the GnRH secretion. Whenthe GnRH secretion is low, the FSH and $\mathrm{LH}$ secretions are also low and so they do not stimulate the gamete production and the gonadal steroid synthesis 27,28 , ${ }^{29}$.The high level of serum ceruloplasmin in infertile women may be due to its role in the ferroxidase activity which is of greatest importance as it converts reduced (ferrous) linked with transferrin to oxidized (ferric) iron linked with ferritin. $\mathrm{Fe}+2$ acts as a pro-oxidant agent because of its readiness to change from one valency state to another. Inits free form, iron is one of the most effective antioxidant catalysts ${ }^{30}$. There are several mechanisms which have beensuggested

forceruloplasminantioxidant activity, including the protecting the organism as a whole from within the possible ill effects caused by the release of free radical oxidation products. This suggests that the organism might respond by raising the antioxidant efficiency of plasma by elevating ceruloplasmin levels ${ }^{31}$. The results of this study are similar to the study of Al-Helalyand Al-Kado on infertile females in which they showed that higher levels of ceruloplasmin were in infertile women rather than in the control group ${ }^{32}$. In this study, we revealed significant highly increase in the serum MDAlevel in patients with infertility in comparison with control females. These results are in agreeswith other study published elsewhere in the world $^{33,34,32}$. The increase in serum MDA level in 
patients with infertility could be due tochanges in the balance system of oxidants and antioxidants. The elevated MDA levels inserum of infertile women, rather than in the control group, signifies that the oxidative damage in infertile females results from the increase of unsaturated lipid peroxidation of various cells including ova cells. The elevated MDA levels, are indicators of a state of oxidative stress in infertile females. MDA is an indicator of lipid peroxidation and increased levels of the peroxidation products which have been associated with a variety of acute and chronic pathophysiological processes in human beings 35 .

\section{CONCLUSION:}

The results of this study indicate that oxidative stress does occur in infertile females. Patients with infertility showed are higher significant rise in serum Prolactin hormone and thyroid-stimulating hormone levels in infertility patient group. All the patients with a high Prolactin level should have TSH estimation.

\section{REFERENCES:}

1- Campbell $S$ and Monga A. Gynecology by Ten Teachers, 2004; pp 12-182

2- Merz E, Miric D, and Bahlmann F. Sonographic size of uterus andovaries in pre and postmenopausal women. Ultrasound ObstetGynecol. 1996; 7:38-42

3- Chan C.C, Ng E.H, Lic F and Ho P.C. Impaired ovarian blood flowand reduced antral follicular count following laproscopic salpingectomy for ectopic pregnancy. Human reproduction 2003, $18: 2175-2180$

4- Kalsum A, Jalali S. Role of hyperprolactenemia in infertility. Pakistan J Med Res 2002, 41 (3):18
5- Padubiri VG, Daftary SN. Physiology. In: Shaw's textbook of Gynaecology, 13th edition, Elsevier, New Delhi, 2004: 38-47

6- Halliwell B, Gutteridge JMC. Free radicals in biology and medicine. $2^{\text {nd }}$ ed. Oxford : Clarendon Press; 1989.

7- Valko M, Leibfritz D, Moncol J, Cronin MT, Mazur M, Telser J. Free radicals and antioxidants in normal physiological functions and human disease. Rview. The International Journal of Biochemistry and Cell Biology, 2007; 39(1): p 44-84 8- Behrman HR, Kodaman PH, Preston SL, Gao S. Oxidative stress and the ovary. J SocGynecolInvestig 2001; 8: S40-S42.

9- Agarwal A, Sajal Gupta and Rakesh K Sharma. Role of Oxidative Strees in Female Reproduction. Reproductive Biology and Endocrinology 2005, 3: 28

10- Agarwal A, Anamar AM, Beena JP, Amani S and Sajal G. The effects of oxidative stress on female reproduction : a review. Reproductive Biology and Endocrinology 2012, 10:49

11- Smith C., Marks A. ,and Lieberman M. "Mark's Basic Medical Biochemistry: A Clinical Approch", $2^{\text {nd }}$ edn. Eds. Lippincott Williams and Wilkins. Philadelphia 2004, p.439-449 12- Hellman NE and Gitlin JD. Ceruloplasmin metabolism and function. Annu Rev Nutr 2002, 22: 439-458

13- Smith D, Gwiazda R, Bowler R, Roels H, Park R, Taicher C, et al. Biomarkers of $\mathrm{Mn}$ exposure in humans. Am J Ind Med 2007, 50: 801811

14- Gutteridge JM. Iron and oxygen radicals in brain. Ann Neurol 1992, 32: S16-S21

15- Farmer EE, Davoine C. "Reactive electrophile species". 
CurrOpin Plant Biol2007, 10 (40) :380-386

16- Moore K, Roberts L J. "Measurement of lipid peroxidtion". Free radic Res 1998, 28(6): 659-671

17- Fong K. L., McCay P. B., and Poyer J. L. J BiolChem 1973, 248: 7792

18- Hart R. Unexplained infertility, endometriosis and fibroids. BMJ 2003, 327(7417):721-724

19- Speroff L, Glass R, Kase N. Clinical Gynecological Endocrinology and Infertility - Lippincott Williams and Wilkins 1999, U.S.A. 1035-1036, 1038-1043.

20- Mohan and Sultana. Follicle Stimulating Hormone, Luteinizing Hormone and Prolactin Levels in Infertile Women in North Chennai, Tamilnadu. J Bio Sci Res 2010, 1(4): 279-289

21- Sunita T, Kanchan S, Avinash T. Hyperprolactinaemia and its Comparison with Hypothyroidism in Primary Infertile Women. Journal of Clinical and Diagnostic Research 2013, 7(5): 794-796

22- Inzucchi SE, Burrow GN: The thyroid gland and reproduction. In Reproductive Endocrinology, SSC Yen, RB Jaffe, RL Barbieri (eds), Philadelphia,W.B. Saunders 1999, pp 413-435

23- Emokpae MA, Uadia PO, Mohammed AZ. Hormonal Evolutions and Endometrial Biopsy in Infertile Women in Kano, Northern Nigeria. Annals of African Medicine 2005, 4: $99-103$

24- Mohammed A. Z. Correlation of Prolactin and Thyroid Hormone Concentration with Menstrual Patterns in Infertile Women. Annals of African Medicine 2003, 4: 3.

25- Nissreen F, Elzobir A, Elhashimi E, Siham MB, Nassr EM, Shrif A. Assessment of Serum Levels of Prolactin in Sudanese female patients with Primary HypothyroidismKhartoum State, Sudan. Asian Journal of Biomedical and Pharmaceutical Sciences 2014, 04(32): 1-4

26- Iqbal NajiTawfiq. Correlation between levels of Serum Prolactin and Total Sialic Acids Concentrations in Fertile and Infertile women. Journal of Al-Nahrain University 2013, 16(2): 145-150

27- Koutras DA. Disturbances of menstruation in thyroid disease. Ann N Y AcadSci 1997, 816:280-284

28- Cramer DW, Sluss PM, Powers RD, McShane P, Ginsburg ES, Hornstein MD, et al. Serum Prolactin and TSH in an In Vitro Fertilization Population: Is There a Link Between Fertilization and Thyroid Function? Journal of Assisted Reproduction and Genetics 2003, 20 (6): 210-215

29- Poppe K, Velkeniers B. Thyroid and infertility. Verh $\mathrm{K}$ AcadGeneeskdBelg 2002, 64(6):38999

30- Philippe A, Gianazza E and Mischel L: Study of acute phase reactants ceruloplasmin. Methods in enzymology1988, 163:441-452

31- Winyard P.G, Hides R C, Brailsford S: Effects of oxidative stress on some physic chemical properties of ceruloplasmin. Biochemical Journal 1989, 258: 435- 445

32- Al-HelalyLuay A. and AlKadoObeda A. Oxidative Stress for Women Infertility in NinavaGovernorate. Journal AlRafedain Science 2012, 23(2): 128147

33- Bhaskar S, SharmilaUpadhya, Satish Kumar Adiga and Pratap Kumar N. Evaluation of oxidative stress, antioxidants and Prolactin in Infertile Women. Indian Journal of Clinical Biochemistry 2008, 23 (2): 186-190 
34- Majid K. Hussain, Hamza JM, Basima S, and Mazin T. Oxidative Stress in Primary Infertility of Women. Global Journal of Medical Research Orthopedic and Musculoskeletal System. 2013, 13(2):Version 1.

35- Yildirim A, Aslan S, Ocak T, Yildirim S, Kara F, Sahin YN.Serum
دراسة مستويات هرمون الحليب ، هرمون محفز الغدة الدرقية،

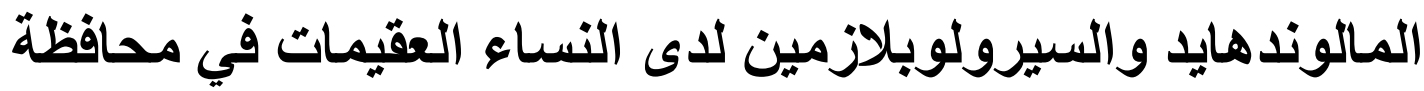

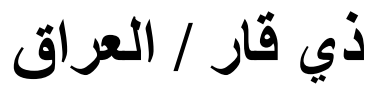

ساهر عبدالرضا علي
Paraoxonase - Arylesterase Activities and MalondialdehydeLevels in Trauma Patients. EAJM 2007, 39: 85-88

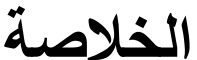

دراسة أجريت لقياس مستوى هرمون الحليب ، هرمون محفز الدرقية ، مالونداي الدئي

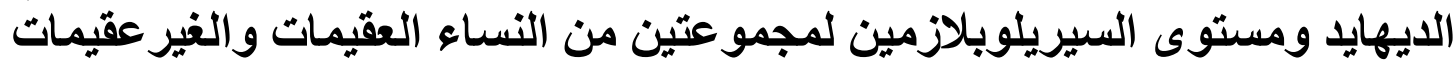

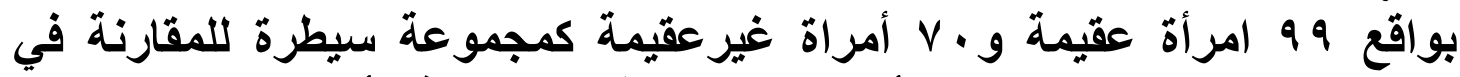

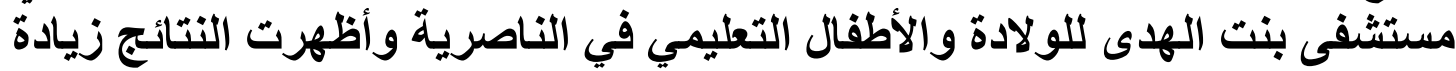

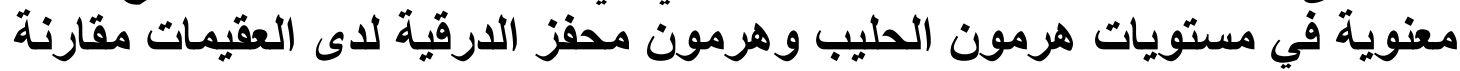

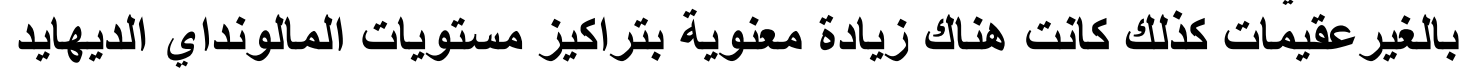

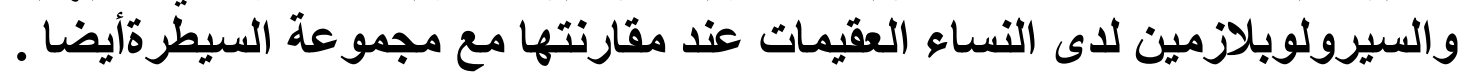

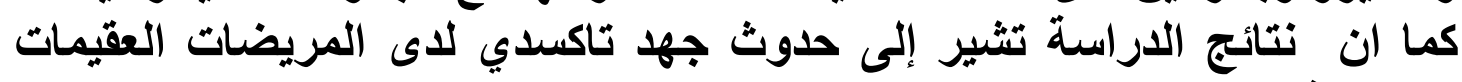

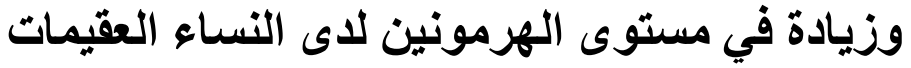

